\title{
Function of Plant DExD/H-Box RNA Helicases Associated with Ribosomal RNA Biogenesis
}

\author{
Yuelin Liu and Ryozo Imai* \\ Institute of Agrobiological Sciences, National Agriculture and Food Research Organization, Tsukuba, Japan
}

Ribosome biogenesis is a highly complex process that requires several cofactors, including $\mathrm{DExD} / \mathrm{H}$-box $\mathrm{RNA}$ helicases $(\mathrm{RH} \mathrm{s})$. $\mathrm{RH}$ s are a family of ATPases that rearrange the secondary structures of RNA and thus remodel ribonucleoprotein complexes. $\mathrm{DExD} / \mathrm{H}$-box $\mathrm{RH}$ s are found in most organisms and play critical roles in a variety of RNA-involved cellular events. In human and yeast cells, many DExD/H box RHs participate in multiple steps of ribosome biogenesis and regulate cellular proliferation and stress responses. In plants, several DExD/H-box RHs have been demonstrated to be associated with plant development and abiotic stress tolerance through their functions in modulating pre-rRNA processing. In this review, we summarize the pleiotropic roles of $\mathrm{DExD} / \mathrm{H}$-box $\mathrm{RH}$ s in rRNA biogenesis and other biological functions. We also describe the overall function of the $\mathrm{DExD} / \mathrm{H}$-box $\mathrm{RH}$ family in ribosome biogenesis based on data from human and yeast.

OPEN ACCESS

Edited by:

Munetaka Sugiyama,

The University of Tokyo, Japan

Reviewed by:

Anca Macovei,

University of Pavia, Italy

Ping Lan,

Institute of Soil Science (CAS), China

*Correspondence.

Ryozo Imai

rzi@affrc.go.jp

Specialty section: This article was submitted to

Plant Cell Biology,

a section of the journal

Frontiers in Plant Science

Received: 31 October 2017

Accepted: 23 January 2018

Published: 08 February 2018

Citation:

Liu Y and Imai $R$ (2018) Function of Plant DExD/H-Box RNA Helicases

Associated with Ribosomal RNA

Biogenesis. Front. Plant Sci. 9:125.

doi: 10.3389/fp/s.2018.00125
Keywords: nucleolus, DExD/H-box RNA helicase, ribosome, development, stress response

\section{INTRODUCTION}

The ribosome is an important molecular machine where mRNA is translated into protein. In eukaryotes, the ribosome consists of a small $40 \mathrm{~S}$ and a large 60S ribonucleoprotein (RNP) subunit. Ribosome biogenesis is a highly complex and fundamental process that comprises the maturation of rRNAs and their assembly with ribosomal proteins (RPs; Panse and Johnson, 2010). Biosynthesis of rRNA initiates with the transcription of $35 \mathrm{~S}$ pre-rRNA and $5 \mathrm{~S}$ rRNA by RNA polymerase I and RNA polymerase III respectively, followed by multiple steps of pre-rRNA processing, modification and folding to yield mature rRNAs (Henras et al., 2008; Woolford and Baserga, 2013). A large number of non-coding RNA and ribosome biogenesis factors (RBFs), such as endoand exoribonuclease, rRNA-modifying enzymes, and RNA helicases (RHs), participate in these processes (Kressler et al., 2010; Lafontaine, 2015). In human cells, mutations in RBFs and RPs usually cause defects in pre-rRNA processing, resulting in various genetic disorders (Narla and Ebert, 2010; Tafforeau et al., 2013). In plants, RBFs and RPs modulate growth and development, affecting processes including leaf morphology, gametogenesis, and embryo development (Byrne, 2009; Weis et al., 2015).

RHs are enzymes that rearrange the secondary structure of RNA and RNP complexes in an energy-dependent manner (Tanner and Linder, 2001). RHs are classified into six subclasses, SF1-SF6, based on specific motif sequences (Gorbalenya and Koonin, 1993; Singleton et al., 2007). SF2 is the major subclass of RHs, and its members share 12 conserved motifs that are involved in ATP hydrolysis, RNA binding, and intramolecular interactions (FairmanWilliams et al., 2010; Linder and Fuller-Pace, 2013). The related DEAH-, DExD-, and $\mathrm{DExD} / \mathrm{H}$-Box families are often referred to as the $\mathrm{DExD} / \mathrm{H}$ family. They, together with the 
DEAD-Box family, constitute the main group of SF2 RHs (Gorbalenya and Koonin, 1993; Fairman-Williams et al., 2010). $\mathrm{DExD} / \mathrm{H}$-box RHs are involved in most cellular events associated with RNA, such as ribosome biogenesis, spliceosome assembly, RNA decay, and RNA editing (Jarmoskaite and Russell, 2014). Recent research has revealed the importance of $\mathrm{DExD} / \mathrm{H}-\mathrm{box}$ RHs in many aspects of plant RNA metabolism and physiological processes. In this review, we will focus on the emerging roles of plant nucleolus $\mathrm{DExD} / \mathrm{H}$-box RHs in rRNA biogenesis, and summarize the current research on their functions in growth and stress responses.

\section{YEAST AND HUMAN DEXD/H-BOX RHs IN RIBOSOME BIOGENESIS}

Over the past several decades, the functions of $\mathrm{DExD} / \mathrm{H}$-box RHs have been widely studied in yeast and human cells. Approximately half of the characterized RHs are associated with various steps in ribosome biogenesis, from rRNA transcription to final ribosome subunit maturations (Martin et al., 2013; Rodríguez-Galán et al., 2013). Most yeast DExD/H-box RHs involved in ribosome biogenesis are essential for cell viability (Rocak and Linder, 2004). However, some are non-essential and their mutants display specific phenotypes. The yeast mutant of $D b p 2$, which functions in both nonsense-mediated mRNA decay and 25S rRNA biogenesis (Bond et al., 2001), displays growth retardation under cold conditions (Barta and Iggo, 1995). Disruptions of Dbp3 and Dbp7, two additional RHs involved in pre-rRNA processing, render a slow growth phenotype under both optimal and cold conditions (Weaver et al., 1997; Daugeron and Linder, 1998). In human cells, deregulation of ribosome-biogenesis-related DExD/H-box RHs is associated with tumorigenesis. DDX21 is highly expressed in breast carcinomas; it can promote tumorigenesis by enhancing RNA processing in breast cancer cells (Zhang et al., 2014). DDX10 is associated with the inv(11)(p15q22) chromosome abnormality which is found in some myeloid leukemia patients (Arai et al., 1997). The NUP98-DDX10 chimeric protein may promote tumorigenesis through altered ribosome assembly or aberrant mRNA transportation (Arai et al., 1997). DDX5 and DDX17 have pro-proliferation or oncogenic functions in cancer development. They are up-regulated in different types of cancer cells, such as colon, prostate, and cutaneous squamous cell carcinoma (Fuller-Pace and Moore, 2011; FullerPace, 2013). Together, these studies suggest that yeast and human $\mathrm{DExD} / \mathrm{H}$-box $\mathrm{RH}$ that are involved in ribosome biogenesis play important roles in maintaining cell proliferation as well as stress adaptation.

\section{BIOLOGICAL ROLES OF RIBOSOME BIOGENESIS RELATED DEXD/H-BOX RHs IN PLANTS}

Plant genomes encode a larger and more diverse $\mathrm{DExD} / \mathrm{H}$ $\mathrm{RH}$ family than is found in other organisms (Linder and
Owttrim, 2009; Xu et al., 2013). Recently, increasing numbers of plant $\mathrm{DExD} / \mathrm{H}$-box RHs have been functionally characterized and their roles in biotic and abiotic stresses as well as plant development have been extensively studied (Table 1). Among these $\mathrm{DExD} / \mathrm{H}$-box RHs, only a small fraction is known to be involved in ribosome biogenesis. AtRH36/SWA3, a homolog of yeast Dbp8p, is the first ribosome biogenesis-related $\mathrm{RH}$ that has been functionally analyzed. Knockdown mutants of AtRH36 display higher accumulations of immature rRNA precursors than WT (Huang et al., 2010a). Loss-of-function of AtRH36 resulted in a disrupted progression of mitosis during female gametophyte development, whereas the RNAi knock-down mutants displayed several defects in growth and development, such as short roots and abnormal leaves (Huang et al., 2010a; Liu et al., 2010). AtRH18 is another essential DExD/H-Box $\mathrm{RH}$ involved in ribosome biogenesis. AtRH18 is a homolog of yeast Sbp4p which participates in the biogenesis of the 60S ribosomal subunit (de la Cruz et al., 1999). Plants with reduced AtRH18 activity show chlorosis, while the knockout mutants are embryo-lethal (Plötner et al., 2017).

Knocking out of non-essential RHs resulted in pleiotropic phenotypes. AtMTR4 is a predominantly nucleolar localized $\mathrm{DExD} / \mathrm{H}$ protein that associates with the RNA exosome complex and functions in rRNA maturation and surveillance (Lange et al., 2011, 2014). A mutation in AtMTR4 increases accumulation of rRNA precursors and rRNA maturation by-products, resulting in several developmental defects, such as delayed embryogenesis, abnormal cotyledons, shorter root, etc. (Lange et al., 2011, 2014). It has been reported that AtRH57 is an ATP-independent $\mathrm{RH}$, and that it can be induced by glucose, ABA, and salt (Hsu et al., 2014). Functional analyses using atrh57 knockout mutants indicated that AtRH57 negatively regulates glucosemediated ABA accumulation and signaling in germination and early seedling development (Hsu et al., 2014). In addition, AtRH57 mutations cause accumulation of abnormal rRNA precursors, hampering small ribosomal subunit formation, which becomes more significant with high levels of glucose (Hsu et al., 2014). Recently, the relationship between DExD/H-box RHs and temperature stress tolerance has been reported in Arabidopsis. AtRH10 is a homolog of human DDX47 and yeast Rrp3p, both of which are involved in ribosome biogenesis (Matsumura et al., 2016). The missense rh10 mutant, impaired in prerRNA processing, shows defects in primary root elongation and leaf development under high temperature (Matsumura et al., 2016; Ohbayashi et al., 2017). AtRH7/PRH75 is a bifunctional RH with RNA unwinding and rewinding activities (Nayak et al., 2013) and is required for pre-rRNA processing (Huang et al., 2016; Liu et al., 2016). The $r h 7$ mutants display pleiotropic phenotypes in growth and development including pointed leaves and disturbed vascular patterns which are also found in ribosome-related mutants (Huang et al., 2016; Liu et al., 2016). The functions of AtRH7 are associated with low-temperature stress. $r h 7$ mutants exhibit severe retardation in germination and defects in leaf morphogenesis under a mild cold stress condition $\left(12^{\circ} \mathrm{C}\right)$, and cannot survive under prolonged $4^{\circ} \mathrm{C}$ treatment (Huang et al., 2016; Liu et al., 2016). Genetic analysis showed that the abnormal accumulation of 
TABLE 1 | List of characterized DEAD-box RHs in Arabidopsis, rice, and maize.

\begin{tabular}{|c|c|c|c|c|}
\hline Plant & Symbol & RNA metabolism & Physiological function & Reference \\
\hline \multirow[t]{32}{*}{ Arabidopsis } & AtRH3 & Chloroplast ribosome biogenesis & Chloroplast development & Asakura et al., 2012 \\
\hline & & roup II intron splicing & ABA response & Gu et al., 2014 \\
\hline & & & Stress tolerance & Lee et al., 2013 \\
\hline & AtRH7 & Ribosome biogenesis & Plant development & Huang et al., 2016 \\
\hline & & & cold tolerance & Liu et al., 2016 \\
\hline & AtRH10 & Ribosome biogenesis & High-temperature tolerance & Matsumura et al., 2016 \\
\hline & AtRH22 & Chloroplast ribosome biogenesis & Chloroplast development & Chi et al., 2012 \\
\hline & & & Seed oil biosynthesis & Kanai et al., 2013 \\
\hline & AtRH36 & Ribosome biogenesis & Female gametogenesis & Huang et al., 2010a \\
\hline & & & & Liu et al., 2010 \\
\hline & AtRH39 & Chloroplast ribosome biogenesis & Chloroplast development & Nishimura et al., 2010 \\
\hline & LOS4 & mRNA export & Stress tolerance & Gong et al., 2002, 2005 \\
\hline & $\mathrm{PMH} 2$ & Group II intron splicing & Unidentified & Köhler et al. (2010) \\
\hline & RCF1 & mRNA splicing & Freezing tolerance & Guan et al., 2013 \\
\hline & STRS1 & Gene silencing & Stress tolerance & Kant et al., 2007 \\
\hline & STRS2 & & & Khan et al., 2014 \\
\hline & ESP3 & mRNA splicing & Embryonic development & Herr et al., 2006 \\
\hline & RID1 & mRNA splicing & Root development & Ohtani et al., 2013 \\
\hline & AtRH57 & Ribosome biogenesis & Glucose and ABA response & Hsu et al.,2014 \\
\hline & ABO6 & Mitochondrial RNA splicing & ABA and auxin signaling & He et al., 2012 \\
\hline & HEN2 & RNA surveillance & Flower development & Western et al., 2002; \\
\hline & & & & Lange et al., 2014 \\
\hline & AtMTR4 & Ribosome biogenesis & Plant development & Lange et al., 2011 \\
\hline & ISE2 & Chloroplast ribosome biogenesis & Plasmodesmata regulation & Carlotto et al., 2016 \\
\hline & & Group II intron splicing & & Bobik et al., 2017 \\
\hline & $\mathrm{AtRH} 2$ & Unidentified & Tombusvirus defense & Kovalev and Nagy, 2014 \\
\hline & AtRH8 & Unidentified & Potyviruses defense & Huang et al., 2010c \\
\hline & AtRH9 & Unidentified & Potyviruses defense & Li et al., 2016 \\
\hline & AtRH18 & Unidentified & Embryonic development & Plötner et al., 2017 \\
\hline & AtRH2O & Unidentified & Tombusvirus defense & Kovalev et al., 2012 \\
\hline & ISE1 & Unidentified & Plasmodesmata regulation & Stonebloom et al., 2009 \\
\hline & AtHELPS & Unidentified & $\mathrm{K}^{+}$tolerance & Xu et al., 2011 \\
\hline \multirow[t]{4}{*}{ Rice } & TOGR1 & Ribosome biogenesis & Thermotolerance & Wang et al., 2016 \\
\hline & OsRH36 & Unidentified & Female gametogenesis & Huang et al., 2010b \\
\hline & OsBIRH1 & Unidentified & Biotic and abiotic stress tolerance & Li et al., 2008 \\
\hline & OsSUV3 & Unidentified & Salt tolerance & Tuteja et al., 2013 \\
\hline \multirow[t]{3}{*}{ Maize } & $\mathrm{ZmRH3}$ & Chloroplast ribosome biogenesis & Unidentified & Asakura et al., 2012 \\
\hline & & Group II intron splicing & & \\
\hline & $\mathrm{ZmDRH} 1$ & Ribosome biogenesis & Unidentified & Gendra et al., 2004 \\
\hline
\end{tabular}

rRNA precursors in $r h 7$ was elevated when these plants were exposed to cold (Huang et al., 2016; Liu et al., 2016); thus, cold may trigger the abnormal phenotypes in the mutant. Interestingly, AtRH7 can physically interact with AtCSP3 (Cold Shock Domain Protein 3), an RNA chaperone involved in cold adaptation (Kim et al., 2013), suggesting that AtRH7 may complex with AtCSP3 to regulate the secondary structure of pre-rRNA, and thus ensure proper pre-rRNA processing in Arabidopsis.

Functions of DExD/H-box RHs as RBFs were also investigated in crop plants. OsRH36 complemented the homologous atrh36-1 mutant and was required for either gametogenesis or fertilization during reproduction in rice (Huang et al., 2010b). Recently, another rice DExD/H-box RH, TOGR1 (Thermotolerant Growth Required 1), was isolated by map-based cloning from a thermosensitive dwarf indica mutant (Wang et al., 2016). The togr1 mutant exhibited high-temperature-dependent dwarf phenotypes. Overexpression of TOGR1 resulted in enhanced thermotolerance as well as increased plant height and yield under high-temperature conditions (Wang et al., 2016). Molecular analyses on the togr1 mutant demonstrated that TOGR1 is associated with U3 snoRNA and is involved in pre-rRNA homeostasis (Wang et al., 2016). When the temperature was raised from 25 to $38^{\circ} \mathrm{C}$, rRNA precursor $P$ - $A 3$ accumulated to a higher level in togr1 mutants than in WT, suggesting a crucial role of TOGR1 in maintaining pre-rRNA processing at high 
temperatures (Wang et al., 2016). In maize, the $\mathrm{DExD} / \mathrm{H}$-box $\mathrm{RH}$, ZmDRH1, has been shown to interact with MA16 and fibrillarin to form a RNP complex involved in rRNA metabolism (Gendra et al., 2004). Collectively, the recent studies of plant DExD/Hbox RHs have revealed multiple roles for these enzymes in plant development and stress adaptation.

\section{POTENTIAL PLAYERS IN RIBOSOME BIOGENESIS}

Considering the fact that about half of the identified $\mathrm{DExD} / \mathrm{H}$ box RHs from human and yeast are RBFs (Rocak and Linder, 2004; Jankowsky et al., 2011; Rodríguez-Galán et al., 2013), we reasoned that there are more $\mathrm{DExD} / \mathrm{H}$-box $\mathrm{RH}$ s associated with rRNA metabolism in plants than have previously been identified. We thus conducted a database search using Ensembl Plants $^{1}$ to identify the homologs of human and yeast $\mathrm{DExD} / \mathrm{H}$ box RHs from Arabidopsis, rice and maize genomes. Twentyeight potential candidates, whose homologs in human and yeast were involved in ribosome biogenesis, were identified in the Arabidopsis genome, whereas 27 and 29 were found in rice and maize, respectively (Table 2 ). A recent proteomic analysis in Arabidopsis identified 1,602 nucleolar proteins, and 519 potential RBFs (Palm et al., 2016). Among these RBFs, 31 were identified as DExD/H-box RHs (Palm et al., 2016). This research together with our database search indicated that over $20 \mathrm{DExD} / \mathrm{H}$-box RHs might participate in ribosome biogenesis in plants, suggesting that many steps in their ribosome biogenesis are RHs dependent, as has been shown in human and yeast.

${ }^{1}$ http://plants.ensembl.org

TABLE 2 | List of rice, maize, and Arabidopsis DExD/H-RHs with homology to human and yeast DExD/H-box RHs which function as RBFs.

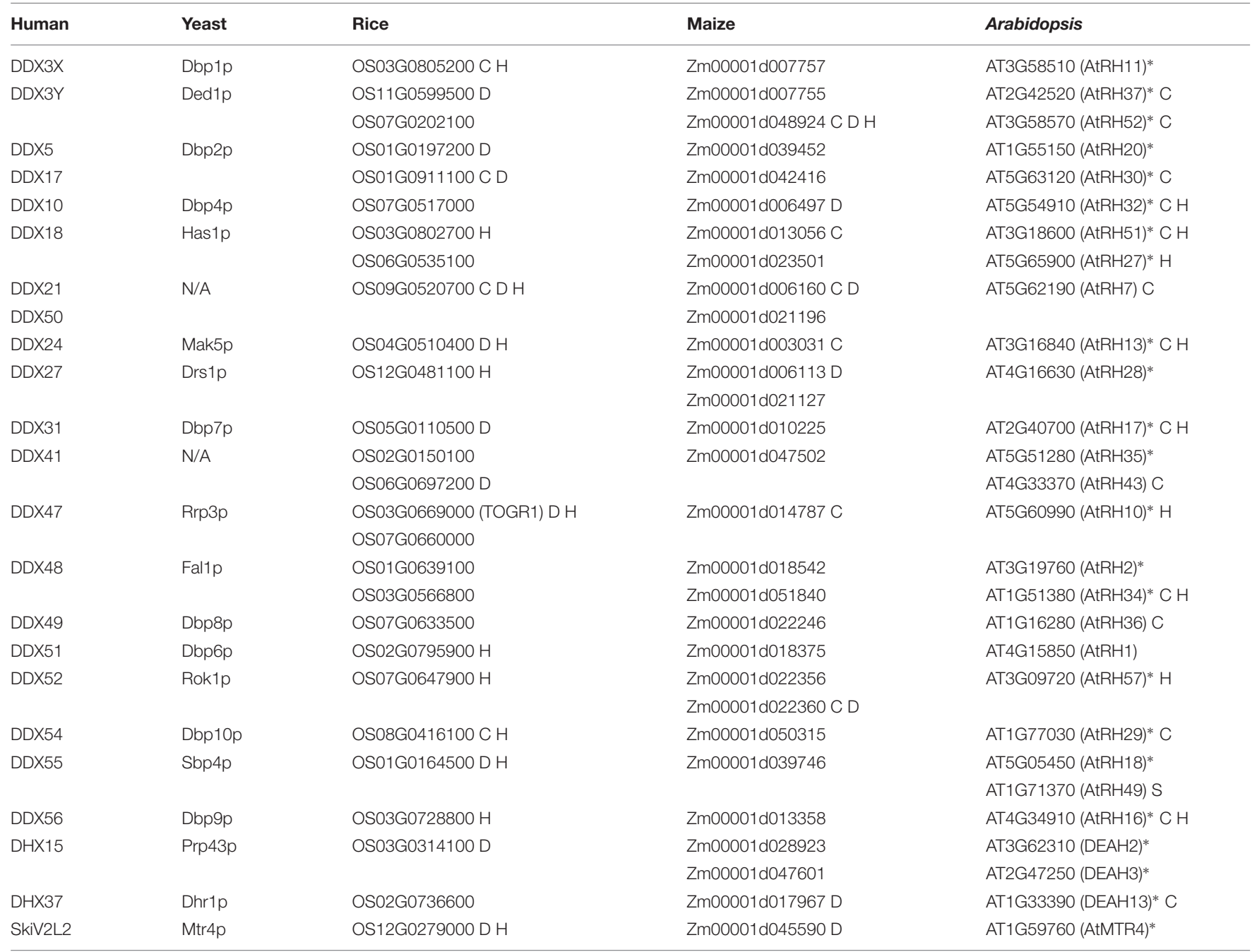

The amino acid sequences of human and yeast DExD/H-box RHs were BLAST-searched against the protein databases of Arabidopsis, rice, and maize available at Ensembl Plants (http://plants.ensembl.org). The protein sequences showing the highest similarity were considered as homologs. Data for abiotic stress-responsiveness were obtained from eFP Brower (http://bar.utoronto.ca/efp arabidopsis/) for Arabidopsis and GENEVESTIGATOR (https://genevestigator.com) for rice and maize. The genes showing a fold change $>2$ are indicated as $C$, cold inducible; $D$, drought inducible; S, salt inducible; and $H$, heat inducible following the annotation numbers. Asterisk "*" indicates the Arabidopsis nucleolar DEAD-box RHs reported as human and yeast RBFs orthologs (Palm et al., 2016). 
Recent studies on AtRH7 and TOGR1 have suggested that stress inducible RBF-type RHs play an important role in modulating plant stress adaptation (Huang et al., 2016; Liu et al., 2016; Wang et al., 2016). This led us to search two plant expression databases, eFP Brower ${ }^{2}$ and GENEVESTIGATOR ${ }^{3}$, to analyze the stress-responsive expression pattern of previously identified candidates. As shown in Table 2, many RH genes are potentially up-regulated by at least one type of stress, implying that these $\mathrm{DExD} / \mathrm{H}$-box $\mathrm{RH}$ may participate in plant stress responses. Ribosome biogenesis is known to be highly coupled with stress stimuli (Boulon et al., 2010); DExD/H-box RHs are critical players in this life process. Therefore, it will be interesting to investigate how these helicases modulate rRNA maturations and how they contribute to plant morphogenesis under stress conditions in future studies.

\section{CONCLUSION AND PERSPECTIVES}

This mini-review has focused on the DExD/H-box RHs which function in pre-rRNA processing in plants. Recent studies have revealed physiological roles of these RHs in plant reproduction, development, and stress responses. However, their precise molecular functions in rRNA biogenesis still remain unclear. Thus, in future studies, it will be necessary to investigate which steps of the pre-rRNA processing these DExD/H-box RHs are involved in, and how they recognize their target rRNA sequence.

\footnotetext{
${ }^{2}$ http://bar.utoronto.ca

${ }^{3}$ https://genevestigator.com
}

\section{REFERENCES}

Arai, Y., Hosoda, F., Kobayashi, H., Arai, K., Hayashi, Y., Kamada, N., et al. (1997). The inv(11)(p15q22) chromosome translocation of de novo and therapyrelated myeloid malignancies results in fusion of the nucleoporin gene, NUP98, with the putative RNA helicase Gene, DDX10. Blood 89, 3936-3944.

Asakura, Y., Galarneau, E., Watkins, K. P., Barkan, A., and van Wijk, K. J. (2012). Chloroplast RH3 DEAD box RNA helicases in maize and Arabidopsis function in splicing of specific group II introns and affect chloroplast ribosome biogenesis. Plant Physiol. 159, 961-974. doi: 10.1104/pp.112.197525

Barta, I., and Iggo, R. (1995). Autoregulation of expression of the yeast Dbp2p 'DEAD-box' protein is mediated by sequences in the conserved DBP2 intron. EMBO J. 14, 3800-3808.

Bobik, K., McCray, T. N., Ernest, B., Fernandez, J. C., Howell, K. A., Lane, T., et al. (2017). The chloroplast RNA helicase ISE2 is required for multiple chloroplast RNA processing steps in Arabidopsis thaliana. Plant J. 91, 114-131. doi: 10. 1111/tpj.13550

Bond, A. T., Mangus, D. A., He, F., and Jacobson, A. (2001). Absence of Dbp2p alters both nonsense-mediated mRNA decay and rRNA processing. Mol. Cell. Biol. 21, 7366-7379. doi: 10.1128/MCB.21.21.7366-7379.2001

Boulon, S., Westman, B. J., Hutten, S., Boisvert, F. M., and Lamond, A. I. (2010). The Nucleolus under Stress. Mol. Cell 40, 216-227. doi: 10.1016/j.molcel.2010. 09.024

Byrne, M. E. (2009). A role for the ribosome in development. Trends Plant Sci. 14, 512-519. doi: 10.1016/j.tplants.2009.06.009

Calo, E., Flynn, R. A., Martin, L., Spitale, R. C., Chang, H. Y., and Wysocka, J. (2014). RNA helicase DDX21 coordinates transcription and ribosomal RNA processing. Nature 518, 249-253. doi: 10.1038/nature13923

Carlotto, N., Wirth, S., Furman, N., Ferreyra Solari, N., Ariel, F., Crespi, M., et al. (2016). The chloroplastic DEVH-box RNA helicase INCREASED SIZE
In human cells, single $\mathrm{DExD} / \mathrm{H}$-box $\mathrm{RH}$ function in a variety of steps in ribosome biogenesis. For instance, DDX47 has a potential role in rRNA transcription in addition to pre-rRNA processing (Sekiguchi et al., 2006; Zhang et al., 2011); DDX21, a homolog of AtRH7, not only regulates pre-rRNA processing but also modulates transcription of rRNA, snoRNAs and RP mRNA (Henning et al., 2003; Calo et al., 2014; Xing et al., 2017). Therefore, it will be interesting to determine if plant $\mathrm{DExD} / \mathrm{H}$-box RHs participate in the transcription of ribosome biogenesis components. Moreover, many DExD/H-box RHs are still uncharacterized but are predicted to be involved in ribosome biogenesis (Table 2). Therefore, future work should be focused on characterizing these potential candidates and revealing their functions in plant growth and stress adaptation. Together, these investigations will provide further insights into the complexity of plant ribosome biogenesis and the intrinsic connection between ribosome biogenesis and plant physiological processes.

\section{AUTHOR CONTRIBUTIONS}

All authors listed have made a substantial, direct and intellectual contribution to the work, and approved it for publication.

\section{ACKNOWLEDGMENTS}

We thank Dr. Linda Jewell (St. John's Research and Development Centre, Agriculture and Agri-Food Canada) for her critical comments on this manuscript.

EXCLUSION LIMIT 2 involved in plasmodesmata regulation is required for group II intron splicing. Plant Cell Environ. 39, 165-173. doi: 10.1111/pce.12603

Chi, W., He, B., Mao, J., Li, Q., Ma, J., Ji, D., et al. (2012). The function of RH22, a DEAD RNA helicase, in the biogenesis of the 50S ribosomal subunits of Arabidopsis chloroplasts. Plant Physiol. 158, 693-707. doi: 10.1104/pp.111. 186775

Daugeron, M. C., and Linder, P. (1998). Dbp7p, a putative ATP-dependent RNA helicase from Saccharomyces cerevisiae, is required for $60 \mathrm{~S}$ ribosomal subunit assembly. RNA 4, 566-581. doi: 10.1017/S1355838298980190

de la Cruz, J., Kressler, D., and Linder, P. (1999). Unwinding RNA in Saccharomyces cerevisiae?: DEAD-box proteins and related families. Trends Biochem. Sci. 24, 192-198. doi: 10.1016/S0968-0004(99)01376-6

Fairman-Williams, M. E., Guenther, U.-P., and Jankowsky, E. (2010). SF1 and SF2 helicases: family matters. Curr. Opin. Struct. Biol. 20, 313-324. doi: 10.1016/j. sbi.2010.03.011

Fuller-Pace, F. V. (2013). DEAD box RNA helicase functions in cancer. RNA Biol. 10, 121-132. doi: 10.4161/rna.23312

Fuller-Pace, F. V., and Moore, H. C. (2011). RNA helicases p68 and p72: multifunctional proteins with important implications for cancer development. Future Oncol. 7, 239-251. doi: 10.2217/fon.11.1

Gendra, E., Moreno, A., Albà, M. M., and Pages, M. (2004). Interaction of the plant glycine-rich RNA-binding protein MA16 with a novel nucleolar DEAD box RNA helicase protein from Zea mays. Plant J. 38, 875-886. doi: 10.1111/j. 1365-313X.2004.02095.x

Gong, Z., Dong, C.-H., Lee, H., Zhu, J., Xiong, L., Gong, D., et al. (2005). A DEAD box RNA helicase is essential for mRNA export and important for development and stress responses in Arabidopsis. Plant Cell 17, 256-267. doi: 10.1105/tpc. 104.027557

Gong, Z., Lee, H., Xiong, L., Jagendorf, A., Stevenson, B., and Zhu, J.-K. (2002). RNA helicase-like protein as an early regulator of transcription factors for plant 
chilling and freezing tolerance. Proc. Natl. Acad. Sci. U.S.A. 99, 11507-11512. doi: 10.1073/pnas.172399299

Gorbalenya, A. E., and Koonin, E. V. (1993). Helicases: amino acid sequence comparisons structure-function relationships. Curr. Opin. Struct. Biol. 3, 419429. doi: 10.1016/S0959-440X(05)80116-2

Gu, L., Xu, T., Lee, K., Lee, K. H., and Kang, H. (2014). A chloroplast-localized DEAD-box RNA helicaseAtRH3 is essential for intron splicing and plays an important role in the growth and stress response in Arabidopsis thaliana. Plant Physiol. Biochem. 82, 309-318. doi: 10.1016/j.plaphy.2014.07.006

Guan, Q., Wu, J., Zhang, Y., Jiang, C., Liu, R., Chai, C., et al. (2013). A DEAD box RNA helicase is critical for pre-mRNA splicing, cold-responsive gene regulation, and cold tolerance in Arabidopsis. Plant Cell 25, 342-356. doi: 10. $1105 /$ tpc. 112.108340

He, J., Duan, Y., Hua, D., Fan, G., Wang, L., Liu, Y., et al. (2012). DEXH box RNA helicase-mediated mitochondrial reactive oxygen species production in Arabidopsis mediates crosstalk between abscisic acid and auxin signaling. Plant Cell 24, 1815-1833. doi: 10.1105/tpc.112.098707

Henning, D., So, R. B., Jin, R., Lau, L. F., and Valdez, B. C. (2003). Silencing of RNA Helicase II/Gu $\alpha$ inhibits mammalian ribosomal RNA production. J. Biol. Chem. 278, 52307-52314. doi: 10.1074/jbc.M310846200

Henras, A. K., Soudet, J., Gérus, M., Lebaron, S., Caizergues-Ferrer, M., Mougin, A., et al. (2008). The post-transcriptional steps of eukaryotic ribosome biogenesis. Cell Mol. Life. Sci. 65, 2334-2359. doi: 10.1007/s00018-008-8027-0

Herr, A. J., Molnar, A., Jones, A., and Baulcombe, D. C. (2006). Defective RNA processing enhances RNA silencing and influences flowering of Arabidopsis. Proc. Natl. Acad. Sci. U.S.A. 103, 14994-15001. doi: 10.1073/pnas.0606536103

Hsu, Y.-F., Chen, Y.-C., Hsiao, Y.-C., Wang, B.-J., Lin, S.-Y., Cheng, W.-H., et al. (2014). AtRH57, a DEAD-box RNA helicase, is involved in feedback inhibition of glucose-mediated abscisic acid accumulation during seedling development and additively affects pre-ribosomal RNA processing with high glucose. Plant $J$. 77, 119-135. doi: 10.1111/tpj.12371

Huang, C.-K., Huang, L.-F., Huang, J.-J., Wu, S.-J., Yeh, C.-H., and Lu, C.-A. (2010a). A DEAD-box protein, AtRH36, is essential for female gametophyte development and is involved in rRNA biogenesis in Arabidopsis. Plant Cell Physiol. 51, 694-706. doi: 10.1093/pcp/pcq045

Huang, C. K., Yu, S. M., and Lu, C. A. (2010b). A rice DEAD-box protein, OsRH36, can complement an Arabidopsis atrh 36 mutant, but cannot functionally replace its yeast homolog Dbp8p. Plant Mol. Biol. 74, 119-128. doi: 10.1007/s11103010-9659-7

Huang, T.-S., Wei, T., Laliberté, J.-F., and Wang, A. (2010c). A host RNA helicaselike protein, AtRH8, interacts with the potyviral genome-linked protein, VPg, associates with the virus accumulation complex, and is essential for infection. Plant Physiol. 152, 255-266. doi: 10.1104/pp.109.147983

Huang, C.-K., Shen, Y.-L., Huang, L.-F., Wu, S.-J., Yeh, C.-H., and Lu, C.-A. (2016). The DEAD-Box RNA helicase AtRH7/PRH75 participates in Pre-rRNA processing, plant development and cold tolerance in Arabidopsis. Plant Cell Physiol. 11, 175-191. doi: 10.1093/pcp/pcv188

Jankowsky, A., Guenther, U. P., and Jankowsky, E. (2011). The RNA helicase database. Nucleic Acids Res. 39, 338-341. doi: 10.1093/nar/ gkq1002

Jarmoskaite, I., and Russell, R. (2014). RNA helicase proteins as chaperones and remodelers. Annu. Rev. Biochem. 83, 697-725. doi: 10.1146/annurev-biochem060713-035546

Kanai, M., Hayashi, M., Kondo, M., and Nishimura, M. (2013). The plastidic DEAD-box RNA helicase 22, HS3, is essential for plastid functions both in seed development and in seedling growth. Plant Cell Physiol. 54, 1431-1440. doi: $10.1093 /$ pcp/pct091

Kant, P., Kant, S., Gordon, M., Shaked, R., and Barak, S. (2007). STRESS RESPONSE SUPPRESSOR1 and STRESS RESPONSE SUPPRESSOR2, two DEAD-box RNA helicases that attenuate Arabidopsis responses to multiple abiotic stresses. Plant Physiol. 145, 814-830. doi: 10.1104/pp.107.099895

Khan, A., Garbelli, A., Grossi, S., Florentin, A., Batelli, G., Acuna, T., et al. (2014). The Arabidopsis STRESS RESPONSE SUPPRESSOR DEAD-box RNA helicases are nucleolar- and chromocenter-localized proteins that undergo stress-mediated relocalization and are involved in epigenetic gene silencing. Plant J. 79, 28-43. doi: 10.1111/tpj.12533

Kim, M., Sonoda, Y., Sasaki, K., Hironori, K., and Imai, R. (2013). Interactome analysis reveals versatile functions of Arabidopsis COLD SHOCK DOMAIN
PROTEIN 3 in RNA processing within the nucleus and cytoplasm. Cell Stress Chaperones 18, 517-525. doi: 10.1007/s12192-012-0398-3

Köhler, D., Schmidt-Gattung, S., and Binder, S. (2010). The DEAD-box protein $\mathrm{PMH} 2$ is required for efficient group II intron splicing in mitochondria of Arabidopsis thaliana. Plant Mol. Biol. 72, 459-467. doi: 10.1007/s11103-0099584-9

Kovalev, N., Barajas, D., and Nagy, P. D. (2012). Similar roles for yeast Dbp2 and Arabidopsis RH20 DEAD-box RNA helicases to Ded1 helicase in tombusvirus plus-strand synthesis. Virology 432, 470-484. doi: 10.1016/j.virol.2012.06.030

Kovalev, N., and Nagy, P. D. (2014). The expanding functions of cellular helicases: the tombusvirus RNA replication enhancer co-opts the plant eIF4AIII-like AtRH2 and the DDX5-like AtRH5 DEAD-box RNA helicases to promote viral asymmetric RNA replication. PLOS Pathog. 10:e1004051. doi: 10.1371/journal. ppat.1004051

Kressler, D., Hurt, E., and Baßler, J. (2010). Driving ribosome assembly. Biochim. Biophys. Acta 1803, 673-683. doi: 10.1016/j.bbamcr.2009.10.009

Lafontaine, D. L. J. (2015). Noncoding RNAs in eukaryotic ribosome biogenesis and function. Nat. Struct. Mol. Biol. 22, 11-19. doi: 10.1038/nsmb.2939

Lange, H., Sement, F. M., and Gagliardi, D. (2011). MTR4, a putative RNA helicase and exosome co-factor, is required for proper rRNA biogenesis and development in Arabidopsis thaliana. Plant J. 68, 51-63. doi: 10.1111/j.1365313X.2011.04675.X

Lange, H., Zuber, H., Sement, F. M., Chicher, J., Kuhn, L., Hammann, P., et al. (2014). The RNA helicases AtMTR4 and HEN2 target specific subsets of nuclear transcripts for degradation by the nuclear exosome in Arabidopsis thaliana. PLOS Genet. 10:e1004564. doi: 10.1371/journal.pgen.1004564

Lee, K.-H., Park, J., Williams, D. S., Xiong, Y., Hwang, I., and Kang, B.-H. (2013). Defective chloroplast development inhibits maintenance of normal levels of abscisic acid in a mutant of the Arabidopsis RH3 DEAD-box protein during early post-germination growth. Plant J. 73, 720-732. doi: 10.1111/tpj.12055

Li, D., Liu, H., Zhang, H., Wang, X., and Song, F. (2008). OsBIRH1, a DEAD-box RNA helicase with functions in modulating defence responses against pathogen infection and oxidative stress. J. Exp. Bot. 59, 2133-2146. doi: 10.1093/jxb/ ern072

Li, Y., Xiong, R., Bernards, M., and Wang, A. (2016). Recruitment of Arabidopsis RNA helicase AtRH9 to the viral replication complex by viral replicase to promote turnip mosaic virus replication. Sci. Rep. 6:30297. doi: 10.1038/ srep30297

Linder, P., and Fuller-Pace, F. V. (2013). Looking back on the birth of DEAD-box RNA helicases. Biochim. Biophys. Acta 1829, 750-755. doi: 10.1016/j.bbagrm. 2013.03.007

Linder, P., and Owttrim, G. W. (2009). Plant RNA helicases: linking aberrant and silencing RNA. Trends Plant Sci. 14, 344-352. doi: 10.1016/j.tplants.2009. 03.007

Liu, M., Shi, D.-Q., Yuan, L., Liu, J., and Yang, W.-C. (2010). SLOW WALKER3, encoding a putative DEAD-box RNA helicase, is essential for female gametogenesis in Arabidopsis. J. Integr. Plant Biol. 52, 817-828. doi: 10.1111/ j.1744-7909.2010.00972.x

Liu, Y., Tabata, D., and Imai, R. (2016). A cold-inducible DEAD-box RNA helicase from Arabidopsis thaliana regulates plant growth and development under low temperature. PLOS ONE 11:e0154040. doi: 10.1371/journal.pone.0154040

Martin, R., Straub, A. U., Doebele, C., and Bohnsack, M. T. (2013). DExD / H-box RNA helicases in ribosome biogenesis. RNA Biol. 10, 4-18. doi: 10.4161/rna. 21879

Matsumura, Y., Ohbayashi, I., Takahashi, H., Kojima, S., Ishibashi, N., Keta, S., et al. (2016). A genetic link between epigenetic repressor AS1-AS2 and a putative small subunit processome in leaf polarity establishment of Arabidopsis. Biol. Open 5, 942-954. doi: 10.1242/bio.019109

Narla, A., and Ebert, B. L. (2010). Ribosomopathies: human disorders of ribosome dysfunction. Blood 115, 3196-3205. doi: 10.1182/blood-2009-10-178129

Nayak, N. R., Putnam, A. A., Addepalli, B., Lowenson, J. D., Chen, T., Jankowsky, E., et al. (2013). An Arabidopsis ATP-dependent, DEAD-box RNA helicase loses activity upon IsoAsp formation but is restored by PROTEIN ISOASPARTYL METHYLTRANSFERASE. Plant Cell 25, 2573-2586. doi: 10. 1105/tpc.113.113456

Nishimura, K., Ashida, H., Ogawa, T., and Yokota, A. (2010). A DEAD box protein is required for formation of a hidden break in Arabidopsis chloroplast $23 \mathrm{~S}$ rRNA. Plant J. 63, 766-777. doi: 10.1111/j.1365-313X.2010.04276.x 
Ohbayashi, I., Lin, C.-Y., Shinohara, N., Matsumura, Y., Machida, Y., Horiguchi, G., et al. (2017). Evidence for a role of ANAC082 as a ribosomal stress response mediator leading to growth defects and developmental alterations in Arabidopsis. Plant Cell 29, 2644-2660. doi: 10.1105/tpc.17.00255

Ohtani, M., Demura, T., and Sugiyama, M. (2013). Arabidopsis root initiation defective1, a DEAH-box RNA helicase involved in pre-mRNA splicing, is essential for plant development. Plant Cell 25, 2056-2069. doi: 10.1105/tpc.113. 111922

Palm, D., Simm, S., Darm, K., Weis, B. L., Ruprecht, M., Schleiff, E., et al. (2016). Proteome distribution between nucleoplasm and nucleolus and its relation to ribosome biogenesis in Arabidopsis thaliana. RNA Biol. 13, 441-454. doi: 10.1080/15476286.2016.1154252

Panse, V. G., and Johnson, A. W. (2010). Maturation of eukaryotic ribosomes: acquisition of functionality. Trends Biochem. Sci. 35, 260-266. doi: 10.1016/j. tibs.2010.01.001

Plötner, B., Nurmi, M., Fischer, A., Watanabe, M., Schneeberger, K., Holm, S., et al. (2017). Chlorosis caused by two recessively interacting genes reveals a role of RNA helicase in hybrid breakdown in Arabidopsis thaliana. Plant J. 91, 251-262. doi: $10.1111 /$ tpj. 13560

Rocak, S., and Linder, P. (2004). DEAD-box proteins: the driving forces behind RNA metabolism. Nat. Rev. Mol. Cell Biol. 5, 232-241. doi: 10.1038/nrm1335

Rodríguez-Galán, O., García-Gómez, J. J., and de la Cruz, J. (2013). Yeast and human RNA helicases involved in ribosome biogenesis: current status and perspectives. Biochim. Biophys. Acta 1829, 775-790. doi: 10.1016/j.bbagrm. 2013.01.007

Sekiguchi, T., Hayano, T., Yanagida, M., Takahashi, N., and Nishimoto, T. (2006). NOP132 is required for proper nucleolus localization of DEAD-box RNA helicase DDX47. Nucleic Acids Res. 34, 4593-4608. doi: 10.1093/nar/gkl603

Singleton, M. R., Dillingham, M. S., and Wigley, D. B. (2007). Structure and mechanism of helicases and nucleic acid translocases. Annu. Rev. Biochem. 76, 23-50. doi: 10.1146/annurev.biochem.76.052305.115300

Stonebloom, S., Burch-Smith, T., Kim, I., Meinke, D., Mindrinos, M., and Zambryski, P. (2009). Loss of the plant DEAD-box protein ISE1 leads to defective mitochondria and increased cell-to-cell transport via plasmodesmata. Proc. Natl. Acad. Sci. U.S.A. 106, 17229-17234. doi: 10.1073/pnas.0909229106

Tafforeau, L., Zorbas, C., Langhendries, J., Mullineux, S., Stamatopoulou, V., Mullier, R., et al. (2013). Resource the complexity of human ribosome biogenesis revealed by systematic nucleolar screening of Pre-rRNA processing factors. Mol. Cell 51, 539-551. doi: 10.1016/j.molcel.2013.08.011

Tanner, N. K., and Linder, P. (2001). DExD/H box RNA helicases: from generic motors to specific dissociation functions. Mol. Cell 8, 251-262. doi: 10.1016/ S1097-2765(01)00329-X

Tuteja, N., Sahoo, R. K., Garg, B., and Tuteja, R. (2013). OsSUV3 dual helicase functions in salinity stress tolerance by maintaining photosynthesis and antioxidant machinery in rice (Oryza sativa L. cv. IR64). Plant J. 76, 115-127. doi: $10.1111 /$ tpj. 12277
Wang, D., Qin, B., Li, X., Tang, D., and Zhang, Y. (2016). Nucleolar DEADbox RNA helicase TOGR1 regulates thermotolerant growth as a Pre- rRNA chaperone in rice. PLOS Genet. 12:e1005844. doi: 10.1371/journal.pgen.10 05844

Weaver, P. L., Sun, C., and Chang, T. H. (1997). Dbp3p, a putative RNA helicase in Saccharomyces cerevisiae, is required for efficient pre-rRNA processing predominantly at site A3. Mol. Cell. Biol. 17, 1354-1365. doi: 10.1128/MCB.17. 3.1354

Weis, B. L., Kovacevic, J., Missbach, S., and Schleiff, E. (2015). Plant-specific features of ribosome biogenesis. Trends Plant Sci. 20, 729-740. doi: 10.1016/j. tplants.2015.07.003

Western, T. L., Cheng, Y., Liu, J., and Chen, X. (2002). HUA ENHANCER2, a putative DExH-box RNA helicase, maintains homeotic $\mathrm{B}$ and $\mathrm{C}$ gene expression in Arabidopsis. Development 129, 1569-1581.

Woolford, J. L., and Baserga, S. J. (2013). Ribosome biogenesis in the yeast Saccharomyces cerevisiae. Genetics 195, 643-681. doi: 10.1534/genetics.113. 153197

Xing, Y. H., Yao, R. W., Zhang, Y., Guo, C. J., Jiang, S., Xu, G., et al. (2017). SLERT Regulates DDX21 rings associated with Pol I transcription. Cell 169, 664-678.e16. doi: 10.1016/j.cell.2017.04.011

Xu, R., Zhang, S., Huang, J., and Zheng, C. (2013). Genome-wide comparative in silico analysis of the RNA helicase gene family in Zea mays and Glycine max: a comparison with Arabidopsis and Oryza sativa. PLOS ONE 8:e78982. doi: 10.1371/journal.pone.0078982

Xu, R. R., Qi, S. D., Lu, L. T., Chen, C. T., Wu, C. A., and Zheng, C. C. (2011). A DExD/H box RNA helicase is important for $\mathrm{K}+$ deprivation responses and tolerance in Arabidopsis thaliana. FEBS J. 278, 2296-2306. doi: 10.1111/j.17424658.2011.08147.x

Zhang, Y., Baysac, K. C., Yee, L., Saporita, A. J., and Weber, J. D. (2014). Elevated DDX21 regulates c-Jun activity and rRNA processing in human breast cancers. Breast Cancer Res. 16:449. doi: 10.1186/s13058-0140449-Z

Zhang, Y., Forys, J. T., Miceli, A. P., Gwinn, A. S., and Weber, J. D. (2011). Identification of DHX33 as a mediator of rRNA synthesis and cell growth. Mol. Cell. Biol. 31, 4676-4691. doi: 10.1128/MCB.05832-11

Conflict of Interest Statement: The authors declare that the research was conducted in the absence of any commercial or financial relationships that could be construed as a potential conflict of interest.

Copyright (c) 2018 Liu and Imai. This is an open-access article distributed under the terms of the Creative Commons Attribution License (CC BY). The use, distribution or reproduction in other forums is permitted, provided the original author(s) and the copyright owner are credited and that the original publication in this journal is cited, in accordance with accepted academic practice. No use, distribution or reproduction is permitted which does not comply with these terms. 